\title{
Potensi Bakteri Bacillus dan Lactobacillus sebagai Probiotik Untuk Mengurangi Pencemaran Amonia pada Kandang Unggas
}

\author{
Potency of Bacillus dan Lactobacillus Bacteria as Probiotik to Reduce Ammonia Pollution \\ in Poultry House
}

\author{
F. Manin, Ella Hendalia, dan Yusrizal
}

Fakultas Peternakan Universitas Jambi

E-mail: manin_105@yahoo.co.id HP: 081366473575

(Diterima: 17 Januari 2012; Disetujui: 10 April 2012)

\begin{abstract}
The experiment was conducted in two phases. The first experiment was to observe the effectivity of six culture of Bacillus and Lactobacillus bacteria for reducing fecal ammonia. The second experiment was to evaluate the application of Bacillus and Lactobacillus bacteria as probiotic for reducing ammonia feses and litter in broiler chicken house and observe its effect on the performance. Six bacteria culture consisting of three species of Bacillus bacteria (Bacillus subtilis, Bacillus cereus and Bacillus thuringiensis) and three species of Lactobacillus bacteria (Lactobacillus acidophillus, Lactobacillus bulgaricus and Streptococcus thermophillus) were used in the first experiment and 200 Day Old Chicks CP 707 were used in application of probiotic at the second experiment. Probiotic treatment were administered by drinking water, sprayed on the litter, combination of drinking water and spraying, and without probiotic as the control. The result of the first experiment showed that the six bacterial cultures and their combination significantly $(P<0,05)$ reduced feses ammonia and $\mathrm{pH}$. The result of the second experiment showed that the probiotic treatment was significantly $(P<0,05)$ reduced ammonia of fresh fecal and litter, but was not significantly improving the performance of the chickens. The conclusion of this experiment was that the combination of six bacterial cultures of Bacillus and Lactobacillus as probiotic was effective to reduce ammonia pollution in poultry house
\end{abstract}

Key Word: Bacillus, Lactobacillus, Probiotics, Ammonia, Broiler

\section{PENDAHULUAN}

Usaha peternakan ayam merupakan salah satu sumber emisi gas ammonia (NH3) yang sangat potensial menimbulkan pencemaran lingkungan. Amonia merupakan gas hasil dekomposisi bahan limbah nitrogen dalam ekskreta, seperti uric acid, protein yang tidak terserap, asam amino dan senyawa non protein nitrogen (NPN) lainnya akibat adanya aktivitas mikroorganisme di dalam feses. Selain mencemari lingkungan, gas $\mathrm{NH}_{3}$ juga dapat menurunkan penampilan ternak, meningkatkan kepekaan ternak terhadap penyakit serta menurunkan efisiensi kerja dari pekerja kandang (Charles dan Haryono, 1991). Dengan demikian pengontrolan ammonia pada kandang unggas sangat penting dilakukan untuk menjamin lingkungan yang lebih sehat dan performans ternak yang lebih baik.
Salah satu cara untuk mengurangi pencemaran ammonia adalah dengan memanfaatkan berbagai spesies mikroba unggul terseleksi sebagai sumber probiotik. Dari beberapa hasil penelitian terdahulu diketahui bahwa suplementasi probiotic dapat mengubah pergerakan mucin dan populasi mikroba di dalam usus halus ayam, sehingga fungsi dan kesehatan usus serta uptake nutrien dapat ditingkatkan (Smirnov et al., 2005). Demikian pula hasil penelitian Mountzouris et al. (2010), menunjukkan bahwa penambahan probiotic secara nyata dapat meningkatkan pertumbuhan ayam broiler, kecernaan nutrien dan AMEn serta komposisi mikroflora pada sekum. Hasil penelitian tersebut memberi indikasi bahwa probiotik memiliki peranan yang sangat berarti dalam menjaga keseimbangan mikroba di dalam saluran pencernaan unggas, sehingga dapat menjaga 
kesehatan ternak dan meningkatkan efisiensi penyerapan zat makanan yang pada akhirnya dapat mengurangi produksi amonia yang berasal hasil dekomposisi limbah nitrogen dalam ekskreta.

Mikroba probiotik yang sudah teridentifikasi pada umumnya berupa Bakteri Asam Laktat (BAL) dan beberapa genus Bacillus. Manin dkk., (2003) telah berhasil mengisolasi dan mengidentifikasi bakteri Bacillus circulans dan Bacillus sp. asal itik lokal Kerinci yang berpotensi untuk digunakan sebagai sumber probiotik. Selanjutnya Manin dkk., (2007) menemukan bakteri Bacillus (Bacillus cereus, B. mycoides, dan B.thuringiensis) dan Lactobacillus ( $L$. acidhophillus dan L. fermentum) pada ayam buras yang dipelihara di lahan gambut yang juga berpotensi sebagai sumber probiotik dan secara inderawi dapat mengurangi bau kandang dalam pemeliharaan ayam broiler. Dari penemuan ini terbuka peluang untuk mengkombinasikan berbagai bakteri Bacillus dan Lactobacillus sebagai probiotik yang memiliki peranan luas, baik untuk mengatasi masalah pencemaran amonia pada kandang unggas maupun untuk memperbaiki efisiensi penggunaan nutrien pada ternak.

Penelitian ini bertujuan untuk 1) Menguji efektifitas berbagai bakteri Bacillus dan Lactobacillus (bakteri penghasil asam, bakteri penghasil antibiotic dan bakteri penghasil protease) dalam menurunkan kadar amnonia feses dan litter pada kandang unggas dan 2) Menguji secara biologis kombinasi bakteri tersebut dalam menurunkan amonia feces dan litter ayam pedaging serta melihat efeknya terhadap performans ternak yang dihasilkan. Melalui penelitian ini diharapkan dapat diperoleh kombinasi unik bakteri probiotik yang efektif untuk mengurangi pencemaran ammonia, sekaligus untuk memperbaiki performan ternak unggas.

\section{METODE}

Penelitian ini dilakukan dalam dua tahap. Tahap pertama bertujuan untuk melihat efektivitas masing-masing bakteri dan kombinasinya dalam menurunkan emisi amonia feses. Enam kultur bakteri yang terdiri atas tiga spesies bakteri Bacillus (Bacillus subtilis, Bacillus cereus dan Bacillus thuringiensis) dan tiga spesies Bakteri Asam Laktat (Lactobacillus acidophillus, Lactobacillus bulgaricus dan Streptococcus thermophillus), baik masing-masing maupun kombinasinya diaplikasikan pada feses pada taraf $0 \%, 5 \%, 10 \%, 15 \%$ dan $20 \%$ (v/w). Sebanyak 50 gram feses dimasukkan ke dalam beaker glass lalu ditambahkan bakteri probiotik dan diinkubasi pada suhu kamar selama 1 jam dan 24 jam sebelum dilakukan pengukuran. Emisi amonia material feses diukur dengan menggunakan Kitagawa Toxic Gas Detector (Kitagawa, Gas Aspirating Pump AP-20) dan ammonia detecting tubes (0,2-20/260 ppm capacity, Komyo Rikagaku Kogyo K.K). Rancangan percobaan yang digunakan adalah Rancangan Acak Lengkap (RAL) terdiri atas 5 perlakuan dengan 5 ulangan.

Penelitian tahap kedua adalah pengujian secara biologis untuk melihat efektivitas penggunaan keenam spesies bakteri sebagai probiotik dalam menurunkan amonia feses dan melihat pengaruhnya terhadap performan ternak. Sebanyak 200 ekor Day Old Chicks CP 707 ditempatkan secara acak ke dalam 20 unit kandang litter, masing-masing sebanyak 10 ekor. Ayam dipelihara selama 5 minggu. Selama pemeliharaan ayam diberi ransum komersial BR 11 tanpa adanya upaya pencegahan penyakit, kecuali vaksinasi NCD. Rancangan percobaan yang digunakan adalah Rancangan Acak Lengkap terdiri atas 4 perlakuan dengan 5 ulangan. Perlakuan yang diterapkan adalah penggunaan probiotik melalui air minum (PM), disemprotkan pada litter (PS), kombinasi antara air minum dan disemprot (PMS) dan tanpa probiotik sebagai kontrol (PO). Pemberian probiotik dilakukan setiap hari di dalam air minum atau disemprotkan di atas litter dengan dosis 10 $\mathrm{ml} /$ liter. Banyaknya probiotik yang disemprotkan adalah $100 \mathrm{ml}$ untuk masingmasing unit percobaan. 
Pada akhir minggu ke 5 pemeliharaan dilakukan pengambilan sampel feses dan litter untuk pengujian kadar ammonia dan $\mathrm{pH}$. Sebanyak 50 gram feses/litter diinkubasi selama 1 jam pada suhu ruang. Setelah diinkubasi dilakukan pengukuran ammonia dan $\mathrm{pH}$. Untuk mengetahui efek penggunaan probiotik terhadap performan ternak dan efisiensi penggunaan pakan, dilakukan penimbangan bobot badan dan penimbangan ransum setiap minggu. Sedangkan pengukuran konsumsi air minum dilakukan setiap hari

\section{HASIL DAN PEMBAHASAN}

\section{Potensi Bakteri Bacillus, Lactobacillus dan Kombinasinya dalam Menurunkan Emisi Amonia Feses}

Bakteri spesifik dan potensinya dalam menurunkan ammonia feses disajikan pada Gambar 1. Berdasarkan data yang diperoleh pada penelitian ini terlihat bahwa masingmasing bakteri memiliki potensi untuk mengurangi emisi ammonia asal feses yang telah diinkubasi selama 1 jam dan 24 jam, dan potensi tersebut akan lebih menonjol bila ke enam kultur Bakteri - Bacillus subtilis (BS), Bacillus cereus (BC), Bacillus thuringiensis (BT ), Lactobacillus acidophillus (LA), Lactobacillus bulgaricus (LB) dan Streptococcus thermophillus (ST) dikombinasikan menjadi suatu probiotik
(MIX). Semakin tinggi taraf aplikasi kultur bakteri secara nyata $(\mathrm{P}<0,05)$ akan menurunkan emisi ammonia feses, dan kadar ammonia terrendah dicapai pada konsentrasi bakteri $20 \%$. Kondisi ini menunjukkan bahwa masing-masing kultur bakteri probiotik yang diujicobakan pada media feses baik secara langsung maupun tidak langsung dapat menghambat proses konversi protein/asam urat yang terdapat dalam feses menjadi ammonia.

Change et al. (1975) dalam Muller (1980), melaporkan bahwa dalam waktu 3,5 jam setelah koleksi, kadar amonia feses dapat meningkat lebih dari enam kali lipat akibat terjadinya proses perombakan asam urat yang sangat cepat. Berkaitan dengan fakta tersebut terbukti bahwa berbagai spesies bakteri yang digunakan dalam penelitian ini, baik secara sendiri-sendiri maupun kombinasinya dapat dimanfaatkan untuk mengurangi emisi amonia yang berasal dari hasil dekomposisi ekskreta, seperti uric acid, protein yang tidak terserap, asam amino dan senyawa non protein nitrogen (NPN) yang berasal dari pakan. Hasil ini juga memberi gambaran bahwa ke enam kultur Bakteri yang digunakan, baik bakteri penghasil asam, bakteri proteolitik dan bakteri penghasil antibiotik, dapat bekerja secara sinergis di dalam suatu probiotik untuk mengurangi emisi amonia pada kandang unggas.

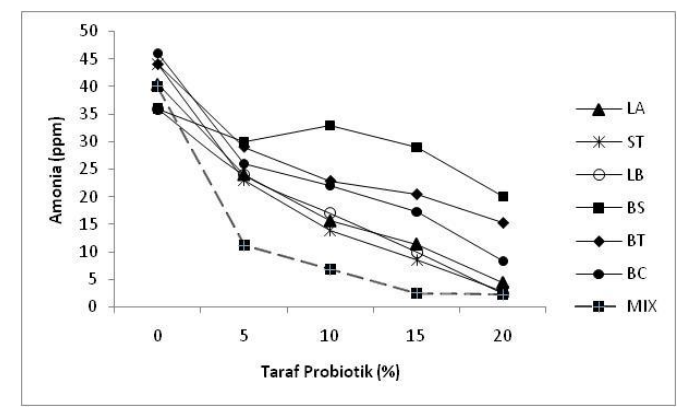

a

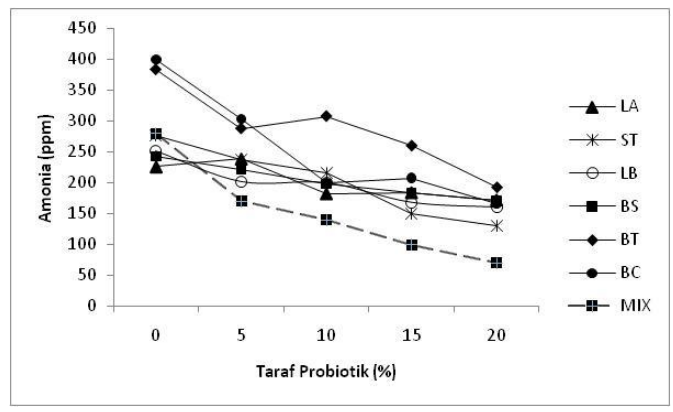

b

Gambar 1.Emisi ammonia feses setelah diinkubasi selama satu jam (a) dan 24 jam (b). $\mathrm{BS}=$ Bacillus subtilis; $\mathrm{BC}=$ Bacillus cereus $; \quad \mathrm{BT}=$ Bacillus thuringiensis; $\mathrm{LA}=$ Lactobacillus acidophillus; $\mathrm{LB}=$ Lactobacillus bulgaricus; $\mathrm{ST}=$ Streptococcus thermophillus dan kombinasi enam bakteri (MIX). 
Hasil penelitian ini sejalan dengan yang dikemukakan oleh Santoso (1999), bahwa bacteri proteolitik, seperti Bacillus sp., dapat menghambat konversi uric acid menjadi ammonia dengan cara menggunakan uric acid tersebut sebagai zat nutrisinya. Demikian pula bakteri penghasil Bacteriocin seperti Streptococcuc thermophilus dapat menurunkan ammonia akibat kemampuannya dalam mencegah keberlanjutan pertumbuhan Salmonella, Coliform dan bakteri pathogenic gram (-) lainnya. Sedangkan bakteri penghasil asam seperti Lactobacillus $s p$, dapat menurunkan $\mathrm{pH}$ feses/litter yang berakibat pada penurunan jumlah dan aktivitas bakteri gram (-).

\section{Pengaruh Aplikasi Probiotik terhadap Emisi Ammonia Feses dan Litter pada Pemeliharaan Ayam Pedaging}

Untuk menguji efectivitas penggunaan kombinasi Bakteri Bacillus dan Bakteri Asam Laktat sebagai probiotik dilakukan percobaan aplikasi probiotik pada ayam pedaging melalui air minum (PM), disemprotkan pada litter (PS) dan kombinasi antara keduanya (PMS). Pada akhir masa pemeliharaan, dilakukan pengambilan sample feses dan litter, kemudian diinkubasi selama 1 jam untuk mengetahui efek penggunaan probiotik tersebut terhadap emisi ammonia, $\mathrm{pH}$ dan kadar air feses dan litter. Data yang diperoleh disajikan pada Tabel 1.

Hasil analisis statistik menunjukkan bahwa aplikasi probiotik memberikan pengaruh yang nyata $(\mathrm{P}<0,05)$ terhadap penurunan emisi amonia feses dan litter, penurunan $\mathrm{pH}$ feses dan kadar air litter, namun tidak nyata $(\mathrm{P}>0,05)$ terhadap penurunan $\mathrm{pH}$ feses dan kadar air litter.

Terjadinya penurunan emisi amonia feses dan litter menunjukkan bahwa probiotik dapat bekerja menurut keunikannya masingmasing sehingga mampu menghambat pertumbuhan dan aktifitas mikroorganisme patogen yang dapat mengkonversi asam urat menjadi amonia. Bacteri proteolitik, seperti Bacillus Sp., dapat menghambat konversi uric acid menjadi ammonia dengan cara menggunakan uric acid tersebut sebagai zat nutrisinya. Demikian pula bakteri penghasil Bacteriocin seperti Streptococcuc thermophilus dapat menurunkan ammonia akibat kemampuannya dalam mencegah keberlanjutan pertumbuhan bakteri pathogenic gram (-). Sedangkan bakteri penghasil asam seperti Lactobacillus sp, dapat menurunkan $\mathrm{pH}$ feses/litter yang berakibat pada penurunan jumlah dan aktivitas bakteri gram (-) (Santoso, 1999).

Tabel 1. Emisi Ammonia, pH dan Kadar Air Feses dan Litter pada Akhir Pemeliharaan.

\begin{tabular}{|c|c|c|c|}
\hline \multicolumn{4}{|c|}{ AMONIA (ppm) } \\
\hline & & & \\
\hline P0 & $16,40 \pm 2,19^{a}$ & $5,96 \pm 0,15^{\mathrm{a}}$ & $55,72 \pm 14,43$ \\
\hline PM & $15,80 \pm 2,95^{\mathrm{a}}$ & $5,16 \pm 0,42^{\mathrm{b}}$ & $63,65 \pm 4,27$ \\
\hline PS & $8,00 \pm 4,12^{\mathrm{b}}$ & $5,16 \pm 0,31^{\mathrm{b}}$ & $66,12 \pm 8,95$ \\
\hline PMS & $10,00 \pm 0,00^{b}$ & $5,64 \pm 0,59^{a b}$ & $59,22 \pm 11,61$ \\
\hline \multicolumn{4}{|c|}{ LITTER } \\
\hline P0 & $52,00 \pm 8,37^{\mathrm{a}}$ & $8,34 \pm 0,15$ & $45,75 \pm 8,21^{\mathrm{a}}$ \\
\hline PM & $40,00 \pm 0,00^{\mathrm{b}}$ & $8,28 \pm 0,19$ & $31,16 \pm 6,16^{b}$ \\
\hline PS & $40,00 \pm 0,00^{b}$ & $8,24 \pm 0,13$ & $40,85 \pm 9,01^{\mathrm{ab}}$ \\
\hline PMS & $40,00 \pm 0,00^{b}$ & $8,24 \pm 0,21$ & $36,11 \pm 7,81^{\mathrm{ab}}$ \\
\hline
\end{tabular}

Keterangan: Superskrip berbeda pada kolom yang sama menunjukkan perbedaan yang nyata $\mathrm{P}<0,05)$. P0 = tanpa probiotik; $\mathrm{PM}=$ aplikasi probiotik melalui air minum; PS = disemprotkan pada $\backslash$ litter; PMS = kombinasi antara PM dan PS. 
Dari data yang diperoleh dalam penelitian ini diketahui bahwa aplikasi probiotik melalui penyemprotan litter (PS) memiliki kemampuan yang lebih baik dalam menurunkan emisi amonia feses dibandingkan perlakuan lainnya. Fakta ini mengindikasikan bahwa aplikasi probiotik melalui penyemprotan secara tidak langsung dapat mempengaruhi keseimbangan bakteri di dalam saluran pencernaan unggas. Hal ini sangat memungkinkan karena ayam memiliki kebiasaan mematuk butir-butir bahan makanan atau benda-benda di sekitar litter, sehingga probiotik yang disemprotkan di atasnya dapat masuk dan berkembang di dalam saluran pencernaan. Hasil ini sejalan dengan hasil yang dilaporkan oleh Wolfenden dkk (2007) bahwa penyemprotan probiotik pada litter sama efektifitasnya dengan probiotik dalam air minum.

Bila diamati dari data $\mathrm{pH}$, terlihat bahwa aplikasi probiotik hanya dapat menurunkan $\mathrm{pH}$ feses, namun tidak nyata dalam menurunkan $\mathrm{pH}$ litter. Penurunan $\mathrm{pH}$ feses erat kaitannya dengan dihasilkannya asam oleh bakteri asam laktat. Seperti yang dikemukakan oleh Lopez (2000), bahwa salah satu mekanisme kerja probiotik adalah menghasilkan asam sehingga akan menurunkan $\mathrm{pH}$ di dalam saluran pencernaan. Dengan menurunnya $\mathrm{pH}$ di dalam saluran pencernaan maka $\mathrm{pH}$ feses pun akan menurun. Seperti yang dikemukakan oleh Sjofjan (2003) bahwa probiotik tidak hanya menjaga keseimbangan ekosistem dalam saluran pencernaan namun juga dapat menahan aktifitas mikroba pengurai protein sehingga menyebabkan kadar amonia feses menurun.

Aplikasi probiotik tidak menyebabkan penurunan $\mathrm{pH}$ litter secara signifikan. Nilai $\mathrm{pH}$ litter yang diperoleh pada penelitian ini masih berada di bawah $\mathrm{pH}$ optimal penguraian uric acid, karena pada umumnya enzim uricase dalam kebanyakan reaksi mempunyai $\mathrm{pH}$ optimum kira-kira $\mathrm{pH} 9.0$ ( Vogels and Drift, 1976 ). Menurut Schefferle (1985), jumlah bakteri pengurai uric acid terdiri dari seperempat dari total populasi bakteri yang ada. Selanjutnya dilaporkan bahwa pada litter yang belum digunakan yang tinggi kadar asamnya hanya mengandung sedikit bakteri uricolytic, sementara litter yang sudah digunakan dan telah menjadi alkaline (basa) mengandung sangat banyak bakteri pengurai uric acid. Dilaporkan pula bahwa populasi bakteri aerobic pengurai uric acid sangat signifikan menghasilkan ammonia dibandingkan ammonia yang diproduksi oleh populasi bakteri anaerobic.

Aplikasi probiotik tidak memberikan pengaruh yang nyata terhadap kadar air feses, namun nyata $(\mathrm{P}<0,05)$ terhadap kadar air litter. Pada Tabel 3 dapat dilihat bahwa kadar air feses pada ayam yang diberi probiotik justru relatif lebih tinggi dibandingkan dengan kontrol $(\mathrm{P}>0,05)$. Tingginya kadar air feses pada ayam yang diberi probiotik sejalan dengan tingginya konsumsi air minum pada masing-masing perlakuan tersebut (Tabel 4). Bila diamati dari data kadar air litter, terlihat bahwa perlakuan PM akan menghasilkan kadar air litter yang paling rendah, sementara pada perlakuan PS dan PMS, penurunan kadar air litter tidak terlihat secara nyata. Penurunan kadar air litter yang tidak nyata pada perlakuan PS dan PMS diduga disebabkan oleh efek penyemprotan sehingga berdampak terhadap tingkat kebasahan litter pada perlakuan tersebut. Walaupun demikian, kadar air litter pada perlakuan PM, PS dan PMS tidak menunjukkan perbedaan yang yang nyata.

\section{Pengaruh Aplikasi Probiotik terhadap Performans Ayam Pedaging}

Data rataan bobot badan, pertambahan bobot badan, konsumsi ransum, konsumsi air minum dan efisiensi penggunaan ransum dapat dilihat pada Tabel 2.

Hasil analisis statistic menunjukkan bahwa penggunaan kombinasi Bakteri Bacillus dan Bakteri Asam Laktat sebagai probiotik tidak menunjukkan pengaruh yang nyata $(\mathrm{P}>0.05)$ terhadap bobot badan, pertambahan bobot badan, konsumsi ransum, konsumsi air minum dan konversi pakan. 
Tabel 2. Pengaruh Aplikasi probiotik terhadap Bobot Badan akhir, Pertambahan Bobot Badan, Konsumsi Ransum, Konsumsi Air Minum dan Konversi Pakan.

\begin{tabular}{lccccc}
\hline Aplikasi & \multicolumn{1}{c}{ KR } & KAM & BB & PBB & FCR \\
\cline { 2 - 6 } Probiotik & gr/e/Minggu & ml/e/Minggu & gr/e & gr/e/Minggu & \\
\hline PO & $597,76 \pm 14,29$ & $1430,75 \pm 39,01$ & $1454.69 \pm 119,29$ & $282.98 \pm 23,89$ & $2,11 \pm 0,16$ \\
PM & $607,15 \pm 26,18$ & $1493,47 \pm 57,95$ & $1559.58 \pm 98,45$ & $303.96 \pm 19,54$ & $2,00 \pm 0,13$ \\
PS & $595,85 \pm 14,53$ & $1491,65 \pm 47,79$ & $1543.54 \pm 61,33$ & $300.63 \pm 12,24$ & $1,98 \pm 0,04$ \\
PMS & $599,79 \pm 18,01$ & $1460,39 \pm 93,30$ & $1560.44 \pm 38,65$ & $304.17 \pm 7,62$ & $1,97 \pm 0,04$ \\
\hline
\end{tabular}

Keterangan: KR=konsumsi ransum; KAM=konsumsi air minum; $\mathrm{BBA}=$ bobot badan akhir penelitian; $\mathrm{PBB}=$ pertambahan bobot badan; FCR= Feed Conversion Ratio/Konversi pakan.

Sekalipun penggunaan probiotik tidak menimbulkan efek yang signifikan terhadap peubah yang diamati, namun berdasarkan data yang diperoleh pada penelitian ini terlihat bahwa ayam yang diberi probiotik memiliki performan yang lebih baik dibandingkan dengan ayam yang tidak diberi probiotik. Bila diamati dari data pada Tabel 2, terlihat bahwa ayam yang diberi probiotik akan menghasilkan rataan bobot badan yang relative lebih tinggi serta konversi pakan yang relative lebih rendah dibandingkan dengan kontrol ( $\mathrm{P} 0)(\mathrm{P}>0,05)$. Hasil ini sesuai dengan hasil yang dilaporkan oleh Smirnov et al. (2005), bahwa suplementasi probiotic dapat memperbaiki fungsi dan kesehatan usus serta meningkatkan uptake nutrien.

Hasil penelitian ini memberi indikasi bahwa probiotik yang diberikan kepada ternak dapat berperan dalam memperbaiki performan ayam broiler, namun peran yang ditunjukkan tidak terlihat secara signifikan. Tidak signifikannya peningkatan performan ternak disebabkan karena probiotik bukanlah zat makanan, tetapi hanya merupakan imbuhan untuk menyeimbangkan komposisi mikroba di dalam saluran pencernaan. Sesuai dengan peranannya, maka efek penggunaan probiotik terhadap peningkatan performan ternak merupakan efek tidak langsung akibat terjadinya penurunan ammonia kandang, peningkatan kesehatan ternak dan perbaikan penyerapan zat makanan. Sebagaimana dilaporkan oleh Caveny et. al, (1981) bahwa ayam broiler yang terekspos ammonia sampai $50 \mathrm{ppm}$ dari umur 1 sampai 49 hari akan mengalami penurunan efisiensi penggunaan pakan secara sangat signifikan. Selanjutnya Kling and Quarles (1974) melaporkan bahwa unggas yang stress akibat ammonia sampai umur 8 minggu akan menghasilkan bobot badan yang nyata lebih rendah.

\section{KESIMPULAN}

1. Kombinasi Bakteri Bacillus subtilis, Bacillus cereus dan Bacillus thuringiensis dengan Lactobacillus acidophillus, Lactobacillus bulgaricus dan Streptococcus thermophillus sebagai Probiotik berpotensi untuk mengurangi pencemaran amonia pada kandang unggas

2. Aplikasi probiotik secara nyata dapat menurunkan emisi ammonia asal feses dan litter, namun tidak nyata dalam memperbaiki performan ayam broiler

3. Probiotik dapat diaplikasikan melalui air minum, disemprotkan pada litter atau kombinasi keduanya.

\section{DAFTAR PUSTAKA}

Burnett, W. E. and Dondero, N. C. 1969. Microbial and chemical changes in poultry manure associated with decomposition and odour generation. Animal Waste Management, Cornell University Conference on Agriculture Waste Management, Page 271.

Caveny, D.D.,C.L. Quarles and G.A., Greathouse, 1981. Atmospheric ammonia and broiler cockerel performance. Poultry Sci. 60:513-516.

Dennis, C. and J. M. Gee 1973. The microbial flora of broiler house and dust. J. of General Micro. 78:101-103. 
Kling, H. F. and C. L. Quarles, 1974. Effect of atmospheric ammonia and the stress of infectious bronchitis vaccination on Leghorn males. Poultry Sci. 53: 1161-1167 .

Lopez, J. 2000. Probiotic in animal nutrition. Recent Advances In Animal Nutrition Asian-Australian Journal of animal Science $55:$ 1238-1246.

Manin F., Ella Hendalia, Yatno, dan I. Putu Kompiang. 2002. Potensi Saluran Pencernaan Itik Lokal Kerinci Sebagai Sumber Probiotik dan Implikasinya Terhadap Produktivitas Ternak dan Penanggulangan kasus Salmonellosis. Laporan Penelitian Hibah Bersaing $\mathrm{X}$ Tahun Pertama. Fakultas Peternakan Universitas Jambi.

Manin F., Ella Hendalia, Yatno, dan I. Putu Kompiang. 2003. Potensi Saluran Pencernaan Itik Lokal Kerinci Sebagai Sumber Probiotik dan Implikasinya Terhadap Produktivitas Ternak dan Penanggulangan kasus Salmonellosis. Laporan Penelitian Hibah Bersaing $X$ Tahun Kedua. Fakultas Peternakan Universitas Jambi.

Manin, F., Ella Hendalia, A.Aziz, 2007. Isolasi dan Produksi Isolat Bakteri Asam Laktat dan Bacillus sp dari Saluran Pencernaan Ayam Buras Asal Lahan Gambut Sebagai Sumber Probiotik. Laporan Penelitian Fundamental Tahun I Fakultas Peternakan Universitas Jambi.

Manin. F., Ella Hendalia, Yusrizal dan Nurhayati. 2006. Effect of Kerinci Duck's Intestinal Probiotic (Bacillus circulans and Bacillus sp) as Feed Addtive on Broiler Performans. Proceedings of The $4^{\text {th }}$ ISTAP “ Animal Production and Sustanable Agriculture in The Tropics" Faculty of Animal Sience, Gajah mada
Uniersity, November $8-9,2006$. p : $276-286$.

Manin. F., Ella Hendalia, Yusrizal, dan Nurhayati. 2005. Efektivitas Probiotik (Bacillus circulans dan Bacillus sp) Asal Saluran Pencernaan Itik Lokal Kerinci Sebagai Pengganti Antibiotik Terhadap Performan Ternak Unggas. Laporan Hibah Bersaing XIII Tahun I.

Mountzouris, K.C., Tsitrsikos, P., Palamidi, I., Arvaniti, A., Mohnl, M., Schatzmayr, G., and Fegeros, K. 2010. Effects of probiotic inclusion levels in broiler nutrition on growth performance, nutrient digestibility, plasma immunoglobulins, and cecal microflora composition. Poult Sci 89: 58-67

Santoso, U.S. Ohtani, K., Tanaka dan Sakaida. 1999. Dried Bacillus subtillis Culture reduced ammonia gass release in poultry house. AsianAustralian Journal of Animal Sciences (AJAS) Vol. 12. No. 5. 677-842.

Schefferle, H. E., 1965. The decomposition of uric acid in built up poultry litter. J. Applied Bacteriology 28: 412-415.

Sjofjan, O. 2003. Kajian probiotik (Aspergillus niger dan Bacillus spp) sebagai imbuhan ransum dan implikasi efeknya terhadap mikrlofora usus serta penampilan produksi ayam petelur. Disertasi Fakultas Pascasarjana. Universitas Padjajaran. Bandung.

Smirnov, A., Perez, R., Amit-Romach, E., Sklan, D., and Uni, Z. 2005. Mucin dynamics and microbial populations in chicken small intestine are changed by dietary probiotic and antibiotic growth promoter supplementation. J Nutr 135: 187-192.

Wolfenden, A.D., Pixley, J.P., Higgins, S.E. Higgins, J.L., Vicente.,Torres, A.,Hargis, B.M., and Tellez, G. 2007. 
Vol. $14(2)$

Evaluation of spray application of a lactobacillus-based probitic on salmonella enteridis colonization in broiler chickens. Fayatelleville. International 